\title{
Identification of SGS 1609 Cellulolytic Bacteria Isolated from Sargassum spec. and Characterization of The Cellulase Produced
}

\section{Identifikasi Bakteri Selulolitik SGS 1609 yang Diisolasi dari Rumput Laut Sargassum spec. dan Karakterisasi Enzim Selulase yang Dihasilkan}

\author{
Yusro Nuri Fawzya ${ }^{1 *}$, Stenny Putri ${ }^{2}$, Nita Noriko², and Gintung Patantis ${ }^{1}$ \\ ${ }^{1}$ Research and Development Center for Marine and Fisheries Product Processing and Biotechnology \\ ${ }^{2}$ Biotechnology Study Program, Faculty of Science and Technology, Indonesia Al-Azhar University \\ *Correspondence Author: Yusro Nuri Fawzya, Petamburan VI Jakarta Pusat 10260, Email: nuri_fawzya@yahoo.com \\ Article history: \\ Received: 4 January 2013; Revised: 18 July 2013; Accepted: 18 July 2013
}

\begin{abstract}
Bacterial isolate from seaweed designated as SGS 1609 was previously found to be able to produce cellulase represented by formation of clear zone on solid medium containing carboxymethylcellulose (CMC). This research was conducted to identify the isolate and determine optimum production time as well as characterize the cellulase produced. The isolate was identified using 16s-rRNA gene analysis. Cellulase production was conducted by cultivating the isolate in the liquid medium containing $\mathrm{CMC}$ followed by centrifuging to get supernatant as the crude enzyme. The enzyme was then concentrated using ammonium sulfate precipitation and ultra filtration. The concentrated enzyme having higher activity produced from the concentration process was then characterized to determine its optimum $\mathrm{pH}$ and temperature, heat stabilization, metal ions effect and substrate specificity. The result showed that the SGS 1609 isolate was identified as Serratia marcescens with $99 \%$ similarity. The isolate produced cellulase optimally at 4 days incubation. Ultra filtration produced higher enzyme activity compared to $\mathrm{NH}_{4}$-sulfate precipitation. The enzyme concentrated by ultra filtration worked optimally at the $\mathrm{pH}$ of 7 , temperature of $50^{\circ} \mathrm{C}$, stable at the temperature of $60^{\circ} \mathrm{C}$ for 240 minutes and was increased its activity by $\mathrm{Ca}^{2+}$ and $\mathrm{Mg}^{2+}$ ions. On the other hand, the enzyme was inhibited by $\mathrm{Fe}^{3+}, \mathrm{Zn}^{2+}$ and $\mathrm{Na}^{+}$ions, but was not relatively affected by $\mathrm{K}^{+}$and EDTA. The use of conventional agar producer waste treated with $6 \% \mathrm{NaOH}$ gave highest activity compared to other substrates.
\end{abstract}

Keywords: SGS 1609 bacterial isolate, identification, cellulase, characterization

\section{ABSTRAK}

Isolat bakteri SGS 1609 diketahui mampu menghasilkan enzim selulase yang direpresentasikan dengan terbentuknya zona bening pada medium padat yang mengandung karboksimetil selulosa (CMC). Penelitian ini dilakukan untuk mengidentifikasi isolat bakteri tersebut dan menentukan waktu produksi optimum serta mengkarakterisasi enzim selulase yang dihasilkannya. Isolat bakteri SGS 1609 diidentifikasi menggunakan analisis sekuen 16s-rRNA. Enzim selulase dihasilkan melalui kultivasi isolat SGS 1609 dalam medium cair yang mengandung CMC, kemudian disentrifus untuk mendapatkan supernatan sebagai ekstrak kasar enzim. Enzim dipekatkan dengan cara pengendapan sulfat dan ultrafiltrasi. Enzim yang memiliki aktivitas lebih tinggi dari proses pemekatan tersebut dikarakterisasi untuk menentukan $\mathrm{pH}$ dan suhu optimum enzim, stabilitas enzim terhadap panas, pengaruh ion logam dan substrat spesifik terhadap aktivitas enzim. Hasil penelitian menunjukkan bahwa isolat bakteri SGS 1609 teridentifikasi sebagai Serratia marcescens dengan kemiripan 99\%. Isolat tersebut memproduksi enzim selulase secara optimal pada inkubasi 4 hari. Pemekatan dengan ultrafiltrasi menghasilkan aktivitas enzim yang lebih tinggi dibandingkan dengan pemekatan menggunakan pengendapan sulfat. Enzim pekat hasil ultrafiltrasi bekerja optimum pada $\mathrm{pH} 7$, suhu $50{ }^{\circ} \mathrm{C}$, stabil pada suhu $60{ }^{\circ} \mathrm{C}$ selama 240 menit. Aktivitas enzim meningkat dengan penambahan ion $\mathrm{Ca}^{2+}$ dan $\mathrm{Mg}^{2+}$, sebaliknya aktivitas enzim dihambat oleh ion $\mathrm{Fe}^{3+}, \mathrm{Zn}^{2+}$ dan $\mathrm{Na}^{+}$, dan relatif tidak terpengaruh oleh penambahan ion $\mathrm{K}^{+}$dan EDTA. Penggunaan limbah agar dari pengolah tradisional yang diberi perlakuan $\mathrm{NaOH} 6 \%$ memberikan aktivitas enzim tertinggi dibandingkan dengan substrat yang lainnya.

Kata Kunci: isolat bakteri SGS 1609, identifikasi, selulase, karakterisasi

Permalink/DOI: http://dx.doi.org/10.15578/squalen.v8i2.87 


\section{Introduction}

The increase of the world enzyme demand stimulates many efforts to find potential enzymes from various sources including microbial enzymes. BCC Research (2011) reported that the global market for industrial enzymes, including technical enzymes, food and beverage enzymes, and others, is expected to reach $\$ 4.4$ billion by 2015 . The most technical enzymes market was predicted found in the leather, followed by bioethanol market. Considered as a renewable fuel, ethanol demand is expected to further increase. A potential source for low-cost ethanol production is to utilize lignocellulosic materials such as agricultural waste, grasses, sawdust etc. Seaweed which is rich in cellulose can serve as an excellent alternative source for bioethanol production.

Considerable studies on the conversion of cellulosic materials to ethanol have been carried out in the last two decades. The conversion includes two processes : hydrolysis of cellulosic materials into fermentable reducing sugars and fermentation to produce bioethanol. So far, commercial ethanol from cellulosic materials employs chemical as well as enzymatic methods of cellulosic materials hydrolysis (Badger, 2002; Glass \& Glass associate, 2013). The enzymatic hydrolysis involves cellulase which is commonly produced by microorganism during their growth on cellulosic materials.

Cellulases are complex enzymes contains of free inducible enzymes. The complete enzymatic hydrolysis of cellulosic materials needs different types of cellulase: endo-1,4- $\beta$-glucanase, also referred to as carboxymethyl cellulase or CMCase (EC 3.2.1.4), exo1,4- $\beta$-glucanase or cellobiohydrolase (EC 3.2.1.91) and $\beta-1,4$-glucosidase (EC 3.2.1.21) (Schulein, 1988 in Sukumaran et al., 2005). These enzymes are widely used in various industries, not only in bioethanol industry, but also in the industry of pulp and paper, textile, detergent, food and feed, brewing and agricultural (Heikinheimo, 2002; lqbal et al., 2004; Karmakar \& Ray, 2011; Kuhad et al., 2011). Most microbial cellulases are produced by fungi, such as Trichoderma, Humicola, and Aspergillus (Sukumaran et al., 2005; Kuhad et al., 2011). However, there is increasing interest in bacterial cellulase since bacteria has high growth rate compared to fungi which has good potential to be used in cellulase production. Studies on bacterial cellulase have been reported including isolation of cellulolytic bacteria from agriculture soil (Meryandini et al., 2009), production of cellulase from Bacillus subtilis YJ1 isolated from fermented food (Yin et al., 2010), characterization of cellulase produced by Streptomyces ruber isolated from marine sediment (El-Sersy et al., 2010), and many others.
Research Centre for Marine and Fisheries Product Processing and Biotechnology has bacterial culture collection, mostly isolated from marine environment, which produce enzymes including cellulases. One of them is bacterial isolate designated as SGS 1609 , isolated from Sargassum spec. -a green seaweed, obtained from Binuangeun, West Jawa. It was reported by Munifah et al. (2011) that the isolate has capability to degrade cellulose substrate with cellulolytic index (Cl) of 5.00. This research was aimed to identify the SGS 1609 bacteria as well as to study the cellulase produced.

\section{Material and Methods}

\subsection{Material}

The SGS 1609 isolate from Sargassum spec. obtained from Binuangeun, West Jawa was used to produce the cellulase. Other materials used were media for bacteria cultivation, and chemicals for enzyme concentration, characterization and activity assay. Molecular biology grade chemicals were used to identify the bacterial isolate based on 16S-rRNA gene sequence analysis.

\subsection{Identification of SGS 1609 Bacteria Isolate}

Bacteria isolate SGS 1609 was identified by 16SrRNA gene analysis based on Suwanto et al. (2000), through the steps of DNA extraction, amplification, sequencing and analyzing. As the supporting data, the isolate was also observed its macroscopic morphology and Gram staining. Genomic DNA extraction was conducted by using Genomic DNA Purification Kit. The DNA was then amplified by the Pure Taq Ready To Go PCR beads (GE Healthcare) with a universal 16S rDNA-63F (52 -CAG GCC TAA CAC ATG CAA GTC-32) and 16S rDNA-1387R (52 GGG CGG WGT GTA CAA GGC-32 ) primer designed by Marchesi et al., (1998). Sequencing of PCR product was done by the First Base Laboratory, Singapore. The sequence was then subjected to BLAST (basic local alignment search tool) analyses to identify the closely related species against a DNA database in the National Center Biotechnology Information (NCBI) database. The related 16S-rRNA gene sequence was aligned by using Clustal $W$ program, and phylogenetic tree was constructed by using the Treecon $1.3 \mathrm{~b}$ program.

\subsection{Bacterial Growth Curve}

Bacterial growth curve was initially prepared by inoculating $5 \mathrm{ml}$ of fresh culture ( $16 \mathrm{~h}$-age) from Nutrient Broth medium into $50 \mathrm{ml}$ of liquid medium containing 
$1 \% \mathrm{CMC} ; 0,02 \% \mathrm{MgSO}_{4} .7 \mathrm{H}_{2} \mathrm{O} ; 0,03 \% \mathrm{NH}_{4} \mathrm{NO}_{3}$; $0,05 \% \mathrm{~K}_{2} \mathrm{HPO}_{4} ; 0,1 \% \mathrm{KH}_{2} \mathrm{PO}_{4} ; 0,002 \% \mathrm{FeSO}_{4} .7 \mathrm{H}_{2} \mathrm{O}$; $0,004 \% \mathrm{CaCl}_{2} .2 \mathrm{H}_{2} \mathrm{O} ; 0,2 \%$ yeast extract; with final $\mathrm{pH}$ of 7.0 , adjusted by using $0.1 \mathrm{~N} \mathrm{NaOH}$. The culture was incubated in a shaker bath at $30^{\circ} \mathrm{C}, 150 \mathrm{rpm}$ for $27 \mathrm{~h}$. Every $3 \mathrm{~h}$ the growth of bacteria was observed by measuring the optical density at $600 \mathrm{~nm}$. Incubation time when the isolate was in the log phase used as the appropriate time to transfer the starter into production medium.

\subsection{Production of Bacterial SGS 1609 Cellulase}

Cellulase production was conducted by inoculating the starter into the production medium which had similar composition with starter medium. The culture was then incubated at $30^{\circ} \mathrm{C}, 150 \mathrm{rpm}$ for 6 days. Everyday sample was taken, sentrifuged at $9000 \mathrm{x}$ $\mathrm{g}, 4^{\circ} \mathrm{C}$ for $10 \mathrm{~min}$., and the activity of the supernatant as crude enzyme was determined using Miller method (Wood \& Saddler, 1988) with modification. Optimum production time was determined as the time which was producing the highest enzyme activity.

\subsection{Assay of Cellulase Activity}

One percent carboxymethyl cellulose (CMC) was dissolved in $1.8 \mathrm{ml}$ of $0.1 \mathrm{M}$ citrate-phosphate buffer $\mathrm{pH} 5$. The solution was then added with $0.2 \mathrm{ml}$ enzyme, and incubated for $30 \mathrm{~min}$ at $30{ }^{\circ} \mathrm{C}$. The reaction was stopped by heating at $100^{\circ} \mathrm{C}$ for $15 \mathrm{~min}$., and $1 \mathrm{ml}$ of the mixture was taken, transferred into a tube, added with $1 \mathrm{ml}$ of DNS and heated at $100^{\circ} \mathrm{C}$ for $15 \mathrm{~min}$. The samples were then cooled to room temperature, and measured at absorbance of $\lambda 575$ $\mathrm{nm}\left(\mathrm{A}_{575}\right)$. Control and blank samples were done simultaneously with the same steps. As a control, the enzyme was firstly inactivated by heating in a waterbath at $100^{\circ} \mathrm{C}$ for 15 min before mixing with the buffer and the substrate. As a blank sample, the enzyme solution was replaced with aquadest to be reacted with the substrate. One unit of cellulase acitivity was defined as the amount of enzyme producing $1 \mu \mathrm{mole}$ of glucose per minute at assay condition.

\subsection{Concentration of the Enzyme}

Concentration of the crude enzyme was carried out by 2 methods, i.e. sulfate precipitation by using ammonium sulfate with saturation percentage of 30 , $40,50,60,70$ and $80 \%$, and ultrafiltration using a UFP-10-C-3MA column, with 10.000 NMWC cut off. The concentrated enzyme produced by the best concentration method was then characterized.

\subsection{Enzyme Characterization}

Optimum $\mathrm{pH}$ was determined through reacting the enzyme with substrate in citrate-phosphate buffer $(\mathrm{pH}$
3-7), and Tris $\mathrm{HCl}$ buffer ( $\mathrm{pH} 8$ and 9), and then the activity was measured at the temperature of $30^{\circ} \mathrm{C}$ for $30 \mathrm{~min}$. according to Miller method (Wood \& Saddler, 1988).

Optimum temperature was determined through reacting the enzyme with substrate at optimum $\mathrm{pH}$ and the temperature of $30,40,50,60,70,80$, and $90^{\circ} \mathrm{C}$ for $30 \mathrm{~min}$., followed by measurement of enzyme activity as described above.

Determination of heat stability of the enzyme was conducted by incubating the enzyme at temperature of 40,50 , and $60^{\circ} \mathrm{C}$ for $15,30,60,90,120$, and 240 minutes, then immediately cooled on ice for a short time. The residual activity was then measured at optimum $\mathrm{pH}$ and temperature condition. Residual activity was expressed as relative activity (\%) of enzyme activity which did not undergo heat treatment.

Effect of EDTA and metal ions $\left(\mathrm{K}^{+}, \mathrm{Na}^{+}, \mathrm{Mg}^{2+}\right.$, $\mathrm{Zn}^{2+}, \mathrm{Ca}^{2+}$, and $\mathrm{Fe}^{3+}$ ) on the enzyme activity was assessed by measuring the enzyme activity which was reacted by 5 and $10 \mathrm{mM}$ EDTA or metal ions (as chloride salts) at optimum $\mathrm{pH}$ and temperature condition. The enzyme activity was presented as relative activity (\%) compared to control, without reacting with EDTA or metal ions.

Evaluation of the substrate specificity was conducted by assessment of cellulase activity on various substrates using carboxymethyl cellulose (CMC) of both technical and pure grade, avicel, Whatman filter paper no.1, company's agar waste treated with $6 \% \mathrm{NaOH}$, conventional agar waste treated with $6 \% \mathrm{NaOH}$, and $1 \% \mathrm{H}_{2} \mathrm{SO}_{4}$, and alginate processing waste. Each substrate was dissolved in buffer within $\mathrm{pH}$ optimum condition and the assay was done at optimum temperature condition.

\section{Results and Discussion}

\subsection{Identification of SGS 1609 Isolate}

Observation on macroscopic morphology of the isolate indicated that the SGS 1609 isolate forms a round shape colony, convex, with the color of white slightly transparent, and $12 \mathrm{~mm}$ in size at the $5^{\text {th }}$-day incubation. Meanwhile, based on the Gram staining result, the short rod shape of the isolate was classified as Gram negative bacterium.

The constructed 16S-rRNA phylogenetic tree indicated that the bacterium had $99 \%$ similarity to Serratia marcescens (Figure 1). Serratia marcescens, a Gram-negative bacillus, rod shaped saprophytic organism, is classified as a member of the Enterobacteriaceae. This bacterium was often used as a biological marker because of its easily 
recognized red colonies (Hejazi \& Falkiner, 1997). The red pigment produced by $S$. marcescens is known as prodigiosin. However, not all strains contained red pigment. This pigment is affected by biomass production. High growth rates of $S$. marcescens influenced in decreasing of cellular prodigiosin concentration. Conversely, low growth rates were associated with increasing pigmentation (Haddix et al., 2008). Prodigiosin biosynthesis also depends on growth condition such as the present of $\mathrm{NaCl}$, illumination, composition of medium etc. (Rjazantseva et al., 1994). This is the probably reason of our observation result related with the colony's color. Khanafari et al. (2006) stated that prodigiosin is a family of natural red pigments characterized by a common pyrrolylpyrromethene skeleton, and having activity as antifungal, immunosuppressan and antiproliferation. This pigment was also reported to be applied to textiles (Liu et al., 2013).
S.marcescens has ability to produce several enzymes, such as lipase (Zaki \& Saeed, 2012), cellulase (Sethi et al., 2013), chitinase (Brurberg et al. 2000), and protease (Joseph et al., 2011). Cellulase of S.marcescens isolated from soil was optimally produced at $40^{\circ} \mathrm{C}$ at $\mathrm{pH} 10$ with glucose as carbon source and ammonium sulfate as nitrogen source (Sethi et al., 2013). However, the characteristics of the cellulase produced were not mentioned.

\subsection{Bacteria Growth Curve}

Bacteria growth was predicted by measuring turbidity or optical density at $\lambda 600 \mathrm{~nm}$. Figure 2 showed that there was no lag phase found at the growth curve. The exponential phase of SGS 1609 isolate was occurred at incubation of $0-3 \mathrm{~h}$. This was because the adaptation of the cell might be faster due to the same composition of both medium, i.e.

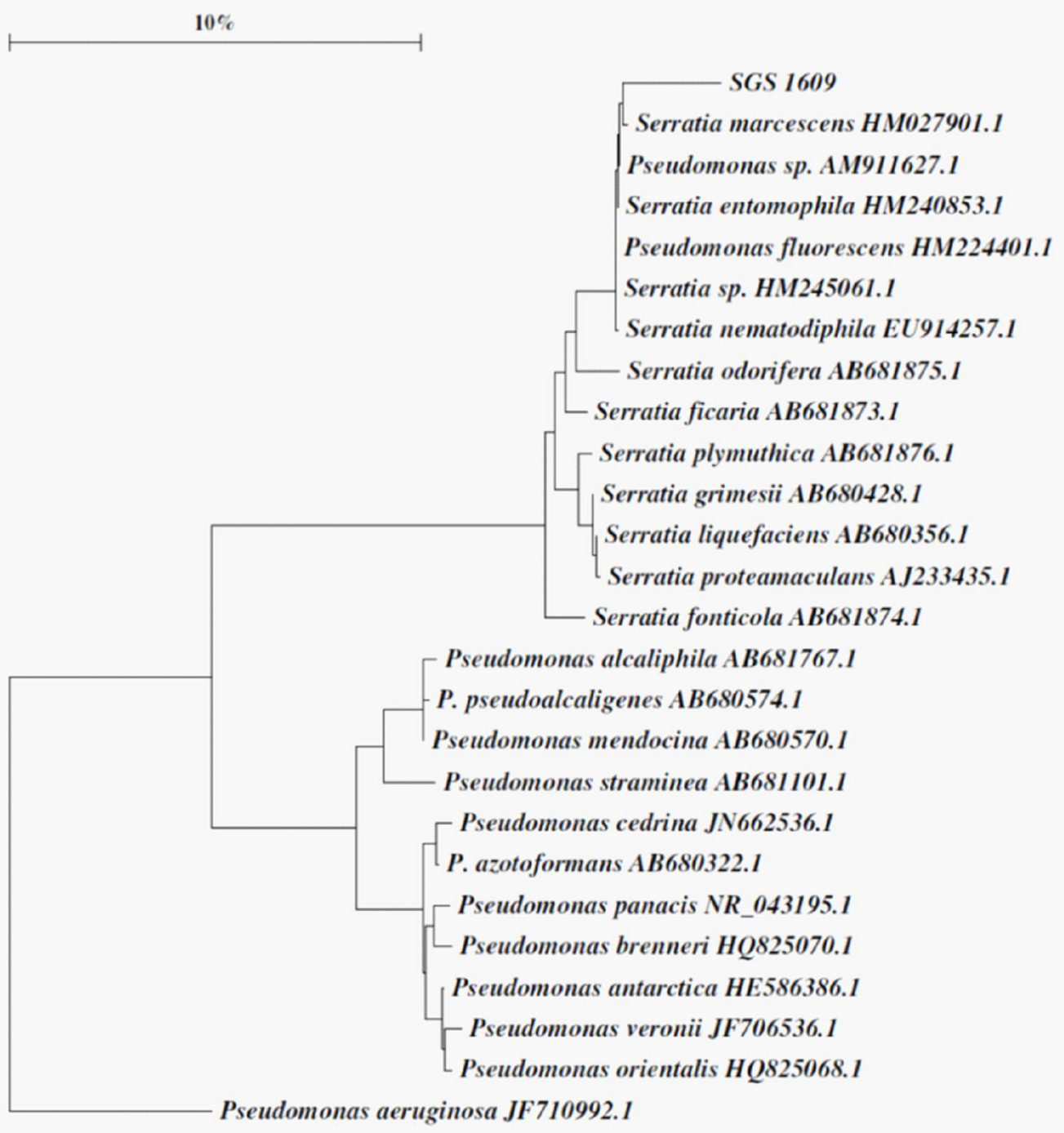

Figure 1. Phylogenetic tree of SGS 1609 isolate. 


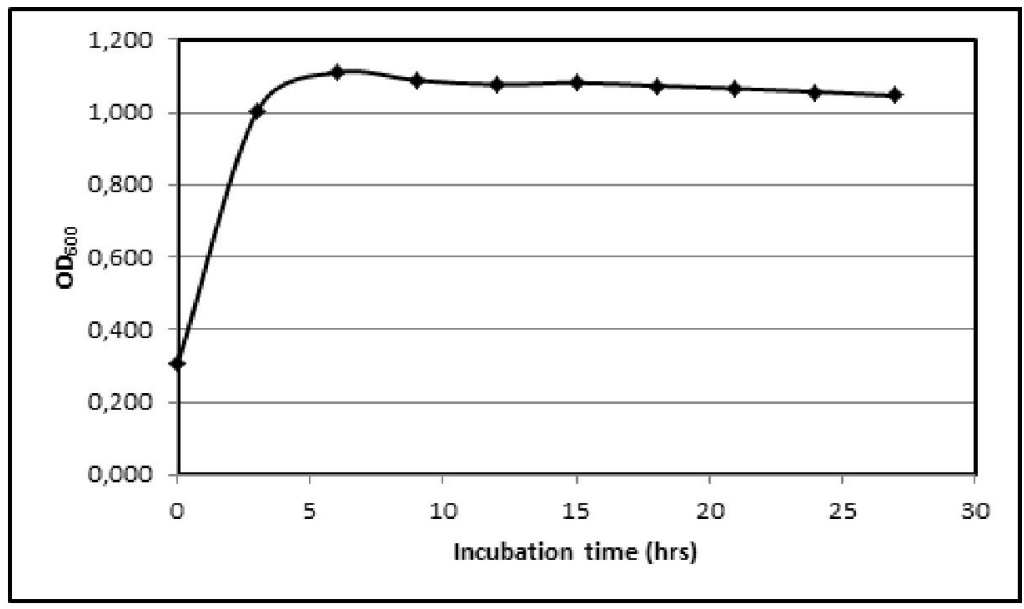

Figure 2. Growth curve of SGS 1609 isolate.

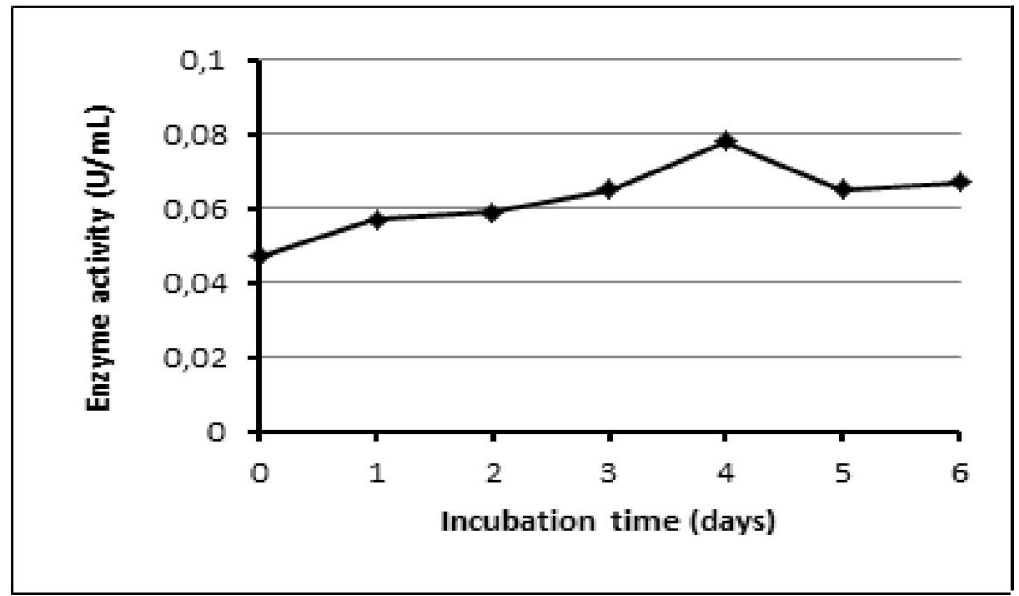

Figure 3. Optimization of cellulase production from SGS 1609 isolate.

medium for starter and for production of enzyme. Based on the curve, incubation time (0-3 hrs) was considered as the appropriate time to transfer the starter into production medium.

\subsection{Production of Bacterial SGS 1609 Cellulase}

The cellulase production was observed during 6days incubation. It was found that at the 0-day incubation, cellulase activity had been detected which was probably because the starter had been producing cellulase when it was added into the medium. The optimum production of the cellulase was reached at the incubation time of 4 days with the activity of $0.78 \mathrm{U} /$ $\mathrm{ml}$. Eventhough observation on the microbial growth has not been carried out, it is well known that many extracellular enzymes are commonly produced at the end of log phase or at the initial of the stationery phase of the microbial growth. This is because of the limited or depleted nutrient of the cultivation medium at that growth phase. In this research, the nutrient source was derived from yeast extract. Thus, in the $4^{\text {th }}$-day incubation, the SGS 1609 isolate was predicted in the stationary phase. At the next incubation time, the culture had to secrete its enzyme to digest substrate contained in the medium; in this case a cellulase was secreted to use carboxymethyl cellulose $(\mathrm{CMC})$ as the nutrient source (Meryandini et al., 2009). Various substrates may be used as carbon sources of cellulase producing bacteria, such as cellulose, filter paper, CMC, starch or cellobiose, however, $\mathrm{CMC}$ is the best carbon source for cellulase production as reported by Das et al. (2010).

Each microorganism has different production time and yield of its enzymes. As reported by Meryandini et al. (2009), bacterial isolate obtained from soil has an optimum cellulase production time of 2-3 days when was cultivated on a straw substrate. The highest enzyme production of Streptomyces ruber is detected after 7 days of incubation (El Sersy et al., 2010). Cellulomonas sp. YJ5 from soil samples optimally 
Table 1. Cellulase activity isolated from SGS 1609 isolate, before and after concentration

\begin{tabular}{cc}
\hline Sample & Enzyme activity $(\mathrm{U} / \mathrm{ml})$ \\
\hline Crude extract before concentration & 0.065 \\
Crude extract after sulfate precipitation & \\
with \% saturation of : & \\
$30 \%$ & 0.065 \\
$40 \%$ & 0.071 \\
$50 \%$ & 0.067 \\
$60 \%$ & $\mathbf{0 . 0 8 5}$ \\
$70 \%$ & 0.074 \\
$80 \%$ & 0.073 \\
Crude extract after ultrafiltration & $\mathbf{0 . 1 9 0}$ \\
\hline
\end{tabular}

produces cellulase after 48 hours of incubation (Yin et al., 2010a). This difference is mostly depends upon the type of microorganism and condition of medium including $\mathrm{pH}$ value, temperature, presence of inducers, medium additives, aeration, incubation time etc. (Immanuel et al., 2006).

Concentration of enzyme is a part of production and an initial stage of purification. This stage is intended to increase enzyme activity. Table 1 showed that ammonium sulfate precipitation of crude enzyme resulted in maximum activity at addition of $60 \%$ saturation of ammonium sulfate, and the enzyme activity increased by 1.3 times. Ammonium sulfate precipitation has widely been used for concentrating protein/enzyme. The use of ammonium sulfate at the initial step of microbial cellulase purification is at saturation levels of $40-80 \%$ as reported by Chen et al. (2004), Makky (2009) and Yin et al., (2010b). The enzyme activities increase by 1.2 to 50.4 fold. Ultrafiltration with 10.000 NMWC cut off, increased enzyme activity up to 2.9 times. This method basically separates the protein/enzyme from other impurities. Protein with molecular weight (MW) less than $10 \mathrm{kDa}$ moves out of the membrane, while that molecule larger than $10 \mathrm{kDa}$ retained in the membrane. Microbial cellulases commonly have MW in the range of 20 to $170 \mathrm{kDa}$. The enzyme with MW of $20 \mathrm{kDa}$ has been reported by El-Sersy et al. (2010) who found cellulase type II from Streptomyces ruber with the MW of 24 $\mathrm{kDa}$, and 1,4 $\beta$-glucanase from Aspergillus terreus M11 with MW of $25 \mathrm{kD}$ (Gao et al., 2007). Meanwhile, cellulase with $170 \mathrm{kDa}$ in MW has been found from Bacillus pumilus mutant with the MW of 80 and 170 $\mathrm{kDa}$ (Kotchoni et al., 2006).

Based on Table 1, concentration by using ultrafiltration produced higher activity of cellulase.
Thus, further analyses was conducted using the cellulase concentrated by ultrafiltration.

\subsection{Enzyme Characterization}

The SGS 1609 cellulase exhibited highest activity at pH 7 (Fig. 4). However, the enzyme activity in a pH range of 3 to 9 were not different so much, ranging from $0.064-0.075 \mu / \mathrm{ml}$, indicating that the enzyme worked in a broad range of $\mathrm{pH}$. These values of enzyme activity decreased compared to the activity resulted from ultra filtration process. This was probably because of elapsed time before characterization step. Other cellulase having optimal $\mathrm{pH}$ in a broad range has been reported by Coral et al. (2002) who observed cellulase from Aspergillus niger and found that the enzyme has a wide $\mathrm{pH}$ range between 3.0 and 9.0 with two major activity peaks at $\mathrm{pH} 4.5$ and 7.5 . Similar character is shown by Bacillus strain M-9 cellulase which has activity in a broad range of $\mathrm{pH}(3-10)$ with the maximum activity at pH 5 (Bajaj et al., 2009). Cellulase of Pseudomonas sp. also has a broad range of $\mathrm{pH}$ activity (pH 6-8) with optimal pH at 7.5 (Gautam et al., 2010). Whereas, several microbial cellulase have a certain optimal $\mathrm{pH}$ such as carboxymethyl cellulase from Sinorhizobium fredii which works optimally at $\mathrm{pH} 7$ (Chen et al., 2004), or Bacillus subtilis YJ1 cellulase at pH 6-6.5 (Yin et al., 2010b). Optimization of microbial cellulase production has been reported by Sethi et al. (2013). They found that the optimum pH of the fermentation medium for maximum cellulase production from four microbial isolates including Serratia marcescens was 10. This S.marcescens was isolated from soil. However they did not mention the optimum $\mathrm{pH}$ for cellulase activity.

A wide temperature range activity of enzyme was also investigated in this research. At the temperature 


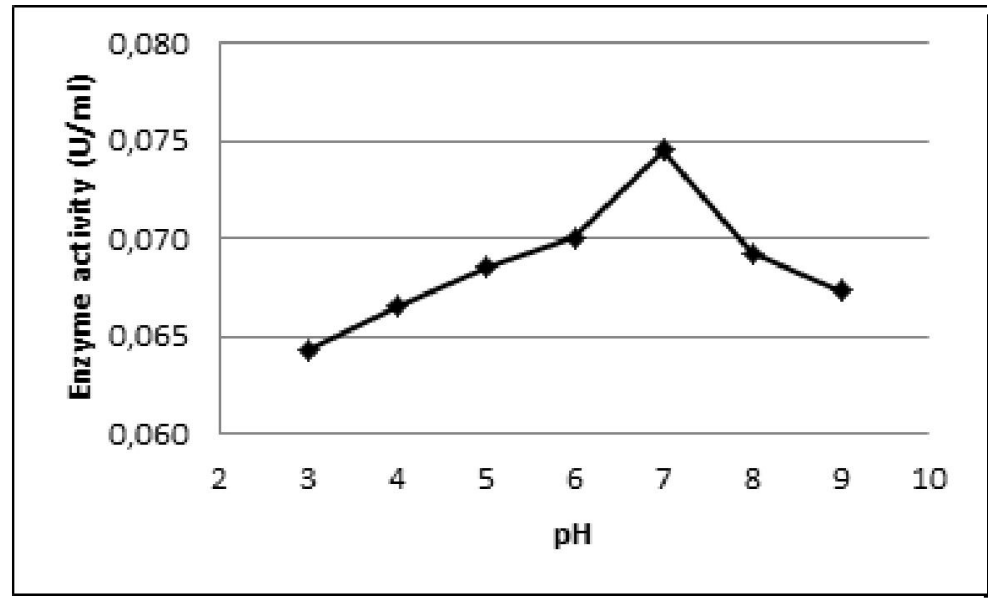

Figure 4. Effect of $\mathrm{pH}$ on the SGS 1609 cellulase activity.

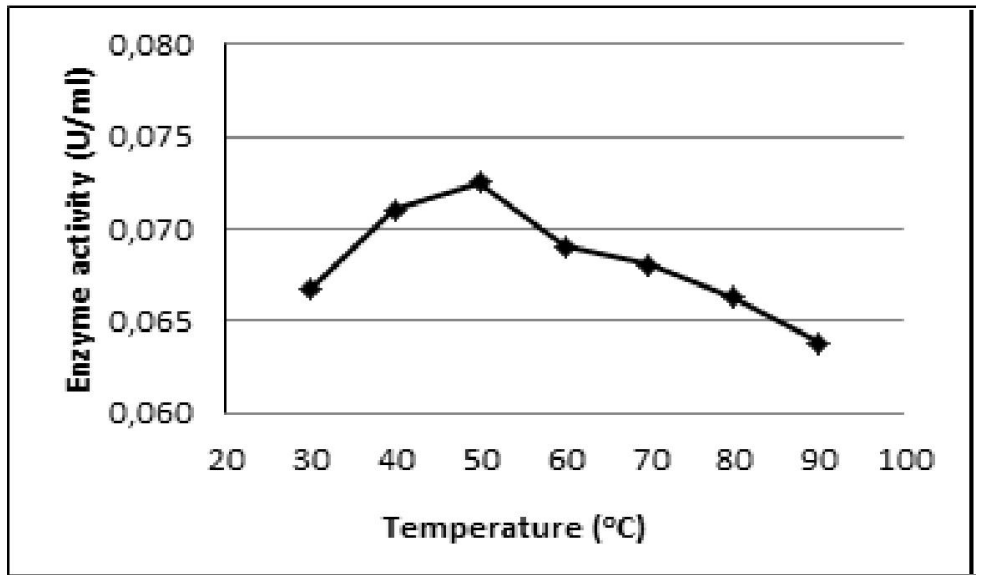

Figure 5. Effect of temperature on the SGS 1609 cellulase activity.

of $50^{\circ} \mathrm{C}$, the cellulase showed highest activity $(0.073$ $\mathrm{U} / \mathrm{ml}$ ). However, slightly variation of activity was detected in the temperature range of $30-90^{\circ} \mathrm{C}$ with the activity ranging from 0.063 to $0.073 \mathrm{U} / \mathrm{ml}$ (Figure 5).

Cellulase produced from Pseudomonas sp. shows maximum activity $(1.359 \mathrm{U} / \mathrm{ml})$ at $40^{\circ} \mathrm{C}$ and works well at temperature between 35 to $45^{\circ} \mathrm{C}$ (Gautam et al., 2010). Generally, microbial cellulases have optimum temperature of about $35-45^{\circ} \mathrm{C}$ (Bajaj et al., 2009). Optimum condition for the activity of cellulase may vary among organisms and within different strains of organism. Compared to other cellulases activity found by other researchers, activity of cellulase produced from SGS 1609 isolate seems lower.This might be due to the difference of enzyme production condition, including medium composition used as carbon and nitrogen sources, $\mathrm{pH}$, temperature and other factor affecting the enzyme produced. Annamalai et al. (2012) demonstrates that cellulase produced from marine bacteria identified as Bacillus licheniformis AU01 reaches the highest activity $(188 \mathrm{U} / \mathrm{ml})$ when produced in medium containing rice bran and peptone as carbon and nitrogen source. The optimum temperature and $\mathrm{pH}$ of $\mathrm{CMCase}$ produced is $50^{\circ} \mathrm{C}$ and 9 respectively, and it is stable at temperature $80^{\circ} \mathrm{C} \mathrm{pH} 12$ with the residual activity reached $80 \%$.

Thermostability test of cellulase produced by SGS 1609 isolate showed that at the temperature range of $40-60^{\circ} \mathrm{C}$, this enzyme demonstrated its good stability for at least 4 hours with the relative activity retained up to $80-90 \%$ (Figure 6). Pons et al. (1995) and Bhat and Bhat (1997) confirm the contribution of disulfide bonds which are commonly found in extracellular proteins, and individual cysteine residues to cellulase protein stability by the protein engineering of Cysteine- 61 and Cysteine- 90 from the $B$. licheniformis glucanase. They proved that disulfide bonds as well as individual cysteine residues contribute in enhancing the thermal stability of the native conformation of proteins. 


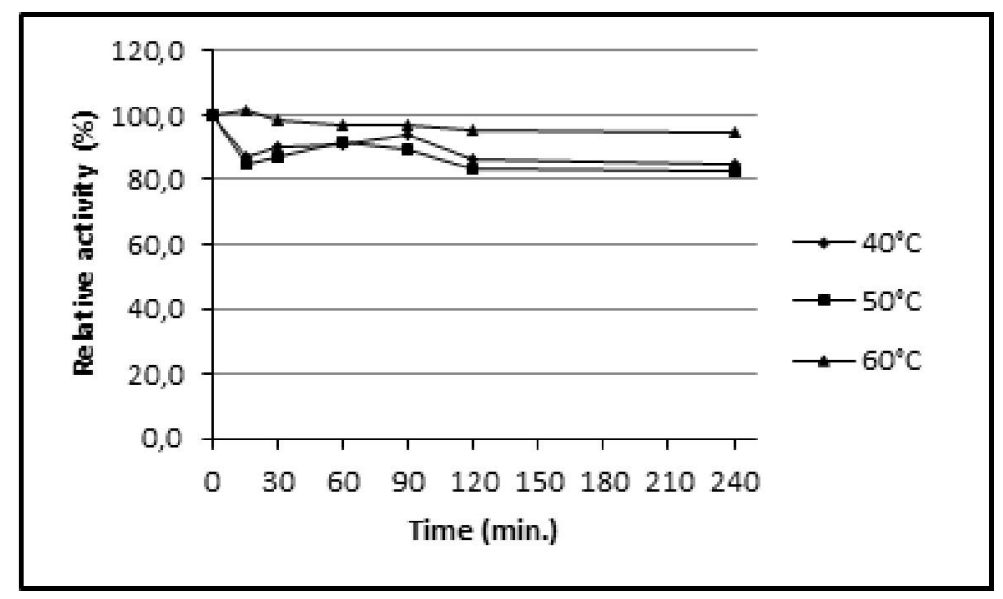

Figure 6. Thermostability of SGS 1609 cellulase.

Some metal ions may be present at significant levels in various industrial process including enzymatic biomass-converting process which maybe derived from addition of reagents, dissolution from a reactor/ pipeline, or brought from water or other raw material sources. According to Li et al. (2005), metal binding of enzymes plays an important role in their activation and stabilization. Thus, metal ions effect is commonly tested as a part of enzyme characterization. Figure 7 presented the effect of metal ions on the celluase activity from SGS 1609 isolate. It was shown that different metals exhibited different effect on the enzyme activity. At the final concentraion of $5 \mathrm{mM}, \mathrm{Ca}^{2+}$ increased the enzyme activity up to $50 \% ; \mathrm{Zn}^{2+}, \mathrm{Fe}^{3+}$ and $\mathrm{Na}^{+}$decreased the activity . Whereas, $\mathrm{Mg}^{2+}, \mathrm{K}^{+}$ and EDTA relatively had no effect on the enzyme activity. Tejirian \& Xu (2010) stated that among the divalent metal ions, most often only $\mathrm{Cu}^{2+}$ and $\mathrm{Fe}^{2+}$ cause strongly inhibition on cellulose-hydrolyzing reactions of cellulase. They used 'cellulase mix' from Novozymes containing Hypocrea jecorina and Aspergillus oryzae cellulases, and also cellulase from wild-type as well as recombinant $H$. jecorina, respectively. However, they mentioned that the mechanism of the cellulase-inhibiting actions of the ions has not been well understood. A recent investigation has been reported by Wang et al. (2013). They found that the inhibition of $\mathrm{Fe}^{3+}$ on cellulasehydrolyzing process is a complicated mechanism which occurs on both enzyme and substrate levels. The $\mathrm{Fe}^{3+}$ inhibition may be reduced by the addition of reducing or chelating agents. However, their result is slightly different from this result. Addition of $10 \mathrm{mM}$ EDTA almost has no effect on Penicillium decumbens cellulase investigated by them, but it reduced the SGS 1609 cellulase by $40 \%$. The SGS 1609 cellulase activity showed slightly decreased at $5 \mathrm{mM}$ concentration of EDTA.
Several substrates were tested to investigate substrate specificity of SGS 1609 cellulase. Among the eight substrates used, agar waste produced by a conventional agar processor from Pameungpeuk, West Jawa, which was pre-treated by $6 \% \mathrm{NaOH}$ gave the highest activity compared to other substrates (Table 2). This is probably because the chemical reduced lignin and other substances bound to cellulose which limit the diffusion of the enzyme into the reaction site of the cellulose. Delignification, a lignin removal process from the lignocelluloses, may occur when strong-acid or -alkali is added to lignocelluloses (Ahmed et al., 2001). Most researcher think that seaweed does not contain lignin, but there are studies revealing that seaweed also contains lignocellulosic material with the amount of about 3-4\% (Santi et al., 2012). Chasanah et al. (2010), however, found that Gracilaria sp., an agarophyte seaweed, contains lignin up to $12 \%$, and the lignin content of agar processing waste is $2.3 \%$. Other reason that might cause the result is the structure of crystalline cellulose underwent transformation to an amorph state due to the addition of $\mathrm{NaOH}$, increasing cellulase accessibility. Compared to substrate derived from agar waste produced by a private company, the later substrate gave a lower cellulase activity. The waste contained lots of celite which was difficult to reduce. Celite is commonly used as a filter aid at filtration step of agar processing. Carboxymethyl cellulose as a model of amorphous cellulose produced relatively the same of cellulase activity with the industrial agar waste treated with $6 \%$ $\mathrm{NaOH}$. Meanwhile, avicel, a microcrystalline cellulose, produced higher cellulase activity than CMC. Crystalline cellulose is degraded by a synergistic action of endoglucanases, cellobiohydrolase and cellobiose (Poulsen \& Petersen, 1991). 


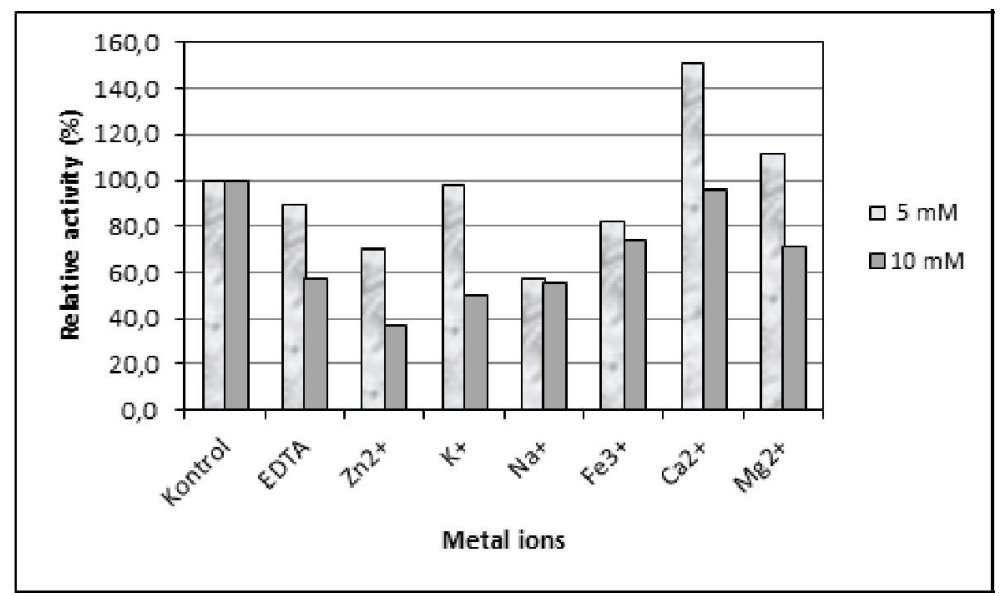

Figure 7. Effect of metal ions and chelator on the SGS 1609 cellulase isolate activity.

Table 2. SGS 1609 cellulase activity on various substrates

\begin{tabular}{clc}
\hline No & \multicolumn{1}{c}{ Substrates } & Cellulase activity $(\mathrm{U} / \mathrm{ml})$ \\
\hline 1 & Pure CMC & 0.088 \\
2 & Technical CMC & 0.072 \\
3 & Avicel & 0.103 \\
4 & Whatman filter paper no.1 & 0.071 \\
5 & Agar waste from an agar private & 0.087 \\
& company, treated with 6\% $\mathrm{NaOH}$ \\
6 & Agar waste from a conventional \\
& $\begin{array}{l}\text { agar producer, treated with 6\% } \\
\text { NaOH }\end{array}$ \\
7 & Agar waste from a conventional agar \\
& producer, treated with 1\% $\mathrm{H}_{2} \mathrm{SO}_{4}$ & 0.134 \\
8 & Alginate waste & 0.078 \\
\hline
\end{tabular}

\section{Conclusion}

The bacteria SGS 1609 isolated from seaweed was identified as Serratia marcescens with $99 \%$ of similarity. The isolate produced cellulase with the highest activity at the $4^{\text {th }}$-day incubation when the bacteria were grown in the MSM medium induced by CMC. Ultrafiltration produced higher activity of concentrated cellulase compared to $\mathrm{NH}_{4}$-sulfate precipitation. The concentrated enzyme produced by ultrafiltration process worked in a wide range of $\mathrm{pH}$ $(4-9)$ and temperature $\left(30-80^{\circ} \mathrm{C}\right)$, with the optimum $\mathrm{pH}$ and temperature was 7 and $50^{\circ} \mathrm{C}$, respectively. The enzyme was stable at the temperature of $60^{\circ} \mathrm{C}$ for 240 minutes. The activity of enzyme was affected by metal ions. It was increased by $\mathrm{Ca}^{2+}$ and $\mathrm{Mg}^{2+}$ ions, but inhibited by $\mathrm{Fe}^{3+}, \mathrm{Zn}^{2+}$ and $\mathrm{Na}^{+}$ions. However, it was not relatively affected by $\mathrm{K}^{+}$and EDTA. Several substrates gave various activities; the highest activity was resulted from the use of agar waste from a conventional agar producer which was treated with $6 \% \mathrm{NaOH}$.

\section{Acknowledgement}

The authors are thankful to Ifah Munifah for her isolation of the bacteria.

\section{References}

Ahmed, Z., Banu, H., Rahman, M. M., Akhter, F., \& Haque, M.S. (2001). Microbial activity on the degradation of lignocellulosic polysaccharides. OnLine Journal of Biological Sciences. 1(10), 993-997.

Annamalai, N., Rajeswari, M. V., Elayaraja, S., Thavasi, R., Vijayalakshmi, S., \& Balasubramanian, T. (2012). Purification and Characterization of Thermostable Alkaline Cellulase from Marine Bacterium Bacillus 
licheniformis AU01 by Utilizing Cellulosic Wastes. Waste and Biomass Valorization. (3)3, 305-310

Badger, P. C. (2002). Ethanol from cellulose: A general review. p. 17-21. In: J. Janick and A. Whipkey (eds.), Trends in new crops and new uses. ASHS Press, Alexandria, VA.

Bajaj, B. K., Pangotra, H., Wani M. A., Sharma, P., \& Sharma, A. (2009). Partial purification and characterization of a highly thermostable and $\mathrm{pH}$ stable endoglucanase from a newly isolated Bacillus strain M-9. Indian Journal of Chemical Technology (16), 382-387.

BCC Research. (2011). Enzymes in Industrial Applications: Global Markets. Report Highlights. Retrived from http://www.bccresearch.com/marketresearch/biotechnology/enzymes-industrialapplications-bio030f.html. Accessed at January 2013.

Bhat, M.K. \& Bhat, S. (1997). Cellulose degrading enzymes and their potential industrial applications. Biotechnology Advances. 15, 583-620.

Brurberg, M.B., Synstad, B., Klemsdal, S.S., Aalten, D.M.F., and Eijsink, V.G.H. 2000. Chitinases from Serratia marcescens. Manuscript 'Recent Research Developments in Microbiology'.14/12/2000. Retrived from http://davapc1.bioch.dundee.ac.uk/pdf/ chirev.pdf. Accessed at 10 February 2013.

Chasanah, E., Fawzya, Y. N., Poernomo, A., Munifah, I., Dewi, A. S., Pratitis, A., \& Patantis, G. (2010). Research on the Utilization of Microorganism and Enzyme for Development of Tropical Catfish Surimi Based Product, Bioenergy from Seaweed Processing Waste and Nutraceutical from Shrimp Waste. Technical Report. Research Centre of Marine and Fishery Product Processing and Biotechnology, Jakarta (in Indonesian).

Chen, P., Wei, T., Chang, Y., \& Lin, L. (2004). Purification and characterization of carboxymethyl cellulose from Sinorhizobium fredii. Bot. Bull. Acad. Sin. 45:111118.

Coral, G., Arikan, B., Unaldi, M.N., \& Guvenments, H. (2002). Some properties of crude carboxymethyl cellulase of Aspergillus niger Zio.Wild type strain.Turk. J. Biol. 2: 209-213.

Das, A., Bhattacharya, S., \& Murali L. 2010. Production of cellulase from a thermophilic Bacillus sp. isolated from cow dung. American-Eurasian J. Agric. Environ. Sci. 8(6), 685-691.

El-Sersy, N. A., Abd-Elnaby, H. , Abou-Elela, G. M., Ibrahim, H.A.H. \& El-Toukhy, N. M. K. (2010). Optimization, economization and characterization of cellulase produced by marine Streptomyces ruber. African Journal of Biotechnology. 9 (38): 6355-6364.

Gao, J., Weng, H., Yu Xi., Daheng, Z., \& Shaoyin, Han. (2007). Purification and characterization of a novel endo-b-1,4-glucanase from the thermoacidophilic Aspergillus terreus. Springer Science, 2007. In Rodrigues, B.S.S (2011). Production and Purification of New Microbial Cellulases. Dissertation. Istituto Superior Tecnico. p. 62.

Gautam, S. P., Bundela, P. S., Pandey, A. K., Jamaluddin, Awasthi, M. K., \& Sarsaiya, S. (2010). Cellulase production by Pseudomonas $\mathrm{sp}$. isolated from municipal solid waste compost. International Journal of Academic Research. 2(6), 330-333.

Glass \& D Glass Associates. (2013). Commercial Cellulosic Ethanol Projects: U.S. and Canada. Retrieved from http://dglass associates. wordpress. com/2013/02/21/commercial-cellulosic-ethanolprojects-u-s-and-canada/. Accessed at 13 March 2013.

Haddix, Pryce L., Jones, Sarah, Patel, Pratik, Burnham, Sarah, Knights, Kaori, Powell, Joan, N., \& LaForm, Amber. (2008). Kinetic analysis of growth rate, ATP, and pigmentation suggests an Energy-Spilling function for the prodigiosin of Serratia marcescens. Bacteriology. 190, 7453-7463.

Heikinheimo, L. (2002). Trichoderma reesei cellulases in processing of cotton. Dissertation for the degree of Doctor of Technology. VTT Technical Research Centre of Finland. pp. 114.

Hejazi, A., \& Falkiner, F. R. (1997). Serratia marcescens. J. Med. Microbiol. 46(11), 903-12.

Immanuel, G., Dhanusha, R., Prema, P., \& Palavesam, A. (2006). Effect of different growth parameters on endoglucanase enzyme activity by bacteria isolated from coir retting effluents of estuarine environment. International Journal of Environmental Science and Technology. 3(1), 25-34.

lqbal, H. M. N., Ahmed, I., Zia, M. A., \& Irfan, M. (2011). Purification and Characterization of the Kinetic Parameters of Cellulase Produced from wheat straw by Trichoderma viride under SSF and its detergent Compatibility. Advances in Bioscience and Biotechnology. (2), 149-156.

Joseph, B. \& Palaniyandi, S. (2011). Determination of Alkaline Protease Production In Serratia marcescens Sp7 Using Agro Wastes As Substrate Medium, Optimization of Production Parameters And Purification Of The Enzyme. World Academy of Science, Engineering and Technology. 50, 247-251.

Karmakar, M. \& Ray, R. R. (2011). Current Trends in Research and Application of Microbial Cellulases. Res. J.of Microbiol. 6(1), 41-53.

Khanafari, A., Assadi, M. M., \& Fakhr, F. A. (2006). Review of Prodigiosin, Pigmentation in Serratia marcescens. OnLine Journal of Biological Sciences. 6(1), 1-13. DOI: 10.3844/ojbsci.2006.1.13.

Kotchoni, S. O., Gachomo, E. W., Omafuvbe, B. O., \& Shonukan, O. O. (2006). Purification and Biochemical Characterization of Carboxymethyl Cellulase (CMCase) from a Catabolite Repression Insensitive Mutant of Bacillus pumilus. International Journal of Agriculture and Biology. 1560-8530/2006/08-2-286292.

Kuhad, R. C., Gupta, R. \& Singh, A. (2011). Microbial cellulases and their industrial applications. Enzyme Research, Article ID 280696, pp 1-10. http://dx.doi.org/ 10.4061/2011/280696.

Li , W. F., Zhou, X. X., \& Lu, P. (2005). Structural features of thermozymes. Research Review Paper. Biotechnology Advances. 23:271-281.

Liu, X., Wang, Y., Sun, S., Zhu, C., Xu, W., Park, Y., \& Zhou, H. (2013). Mutant breeding of Serratia marcesscens strain for enhancing prodigiosin production and 
application to textiles. Preparative Biochemistry and Biotechnology. (43)2, 271-284.

Maki, M., Leung, K.T., \& Qin, W. (tahunnya mana) The prospects of cellulase-producing bacteria for the bioconversion of lignocellulosic biomass. Int. J. Biol. Sci. 5(5), 500-516.

Makky, E. A. (2009). Avicelase Production by a Thermophilic Geobacillus stearothermophilus Isolated from Soil using Sugarcane Bagasse. World Academy of Science, Engineering and Technology.

Marchesi, J. R., Sato, T., Weightman, A. J., Martin, T. A., Fry, J.C., Hiom, S.J., and Wade, W.G. (1998). Design and evaluation of useful bacterium-specific PCR primers that amplify genes coding for bacterial $16 \mathrm{~S}$ rRNA. Appl. Environ. Microbiol. 64, 795-799.

Meryandini, A., Widosari, W., Maranatha, B, Sunarti, T.C., Rachmania, N., \& Satria, H. (2009). Isolation of cellulolytic bacteria and characterization of their enzymes (in Indonesian). Makara Sains. 13(1), 3338.

Munifah, I., Chasanah, E., \& Fawzya, Y.N. (2011). Screening of cellulolytic microbes from Indonesia's marine environment. Paper presented on International Seminar of Indonesian Society for Microbiology (ISISM) and IUMS-Outreach Program on Food Safety at Bali, 22-24 Juni 2011.

Pons, J., Planas, A., \& Querol, E. (1995). Contribution of a disulfide bridge to the stability of 1,3-1,4-P-D-glucan 4-glucanohydrolase from Bacillus licheniformis. Protein Eng. 8: 939-945

Poulsen, O. M. and Petersen, L. W. 1992. Degradation of Microcrystalline Cellulose : Synergism between Different Endoglucanases of Cellulomonas sp. ATCC 21399. Biotechnology and Bioengineering. 39 : 121123

Rjazantseva, I. N., Andreeva, I. N., \& Ogorodnikova, T. I. (1994). Effect of various growth conditions on pigmentation of Serratia marcescens. Micmbios. 79: 155-161.

Santi, R. A., Sunarti, T.C., Santoso, D., \& Triwisari, D.A. (2012). Chemical composition and profile of green seaweed polysaccharides. J. Akuatika. III (2): 105114 (in Indonesian).
Sethi, S., Datta, A., Gupta, B. L., \& Gupta, S. (2013). Optimization of Cellulase Production from Bacteria Isolated from Soil. Research Article. ISRN Biotechnology. Article ID 985685, 7 pages. http:// dx.doi.org/10.5402/2013/985685. Retrieved from : http://www.hindawi.com/isrn/biotechnology/2013/ 985685/ [January 2013]

Sukumaran, R. K., Singhania, R. R., \& Pandhey, A.S. (2005). Microbial Cellulases : Production, applications and challenges. J. of Scientific and Industrial Research. 64:832-844.

Suwanto, Yogiana, Suryanto, D., Tan, I., \& Puspitasari, E. (2000). Selected Protocols Training Course on Advances in Molecular Biology Techniques to Asses Microbial Diversity. Bogor: SEAMEO-BIOTROP. 2231

Tejirian, A. \& Xu, F. (2010). Inhibition of CellulaseCatalyzed Lignocellulosic Hydrolysis by Iron and Oxidative Metal lons and Complexes. Appl Environ Microbiol. 76(23), 7673-7682. doi: 10.1128/ AEM.01376-10.

Wang, M., Mu, Z., Wang, J., Hou, S., Han, L., Dong, Y., Xiao, L., Xia, R., \& Fang, X. (2013). The identification of and relief from $\mathrm{Fe} 3+$ inhibition for both cellulose and cellulase in cellulose saccharification catalyzed by cellulases from Penicillium decumbens. Bioresource Technology. 133, 507-512

Wood, T.M. \& Saddler, J.N. (1988). Increasing the availability of cellulose in biomass materials. In Wood WA and Kellog JA. (Eds). Methode in Enzymology Cellulose and Hemicellulose. New York: Academic Press. 160: 3-11.

Yin, L. J., Huang, P. S., \& Lin, H. H. (2010a). Isolation of Cellulase-Producing Bacteria and Characterization of the Cellulase from the Isolated Bacterium Cellulomonas sp. YJ5. J. Agric. Food Chem. 58, 9833-9837.

Yin, L. J., Lin, H. H., \& Xiao, Z. R. (2010b). Purification and characterization of a cellulose from Bacillus subtilis YJ1. Journal of Marine Science and Technology. 18(3), 466-471.

Zaki, N. H. \& Saeed, S. E. (2012). Production, Purification and Characterization of Extra Cellular Lipase from Serratia marcescens and its Potential Activity for Hydrolysis of Edible Oils. Journal of Al-Nahrain University. 15(1), 94-102. 